\title{
Loss of Highly Influential Figure in Social Anthropology: A Tribute to Fredrik Barth
}

\section{Madhusudan Subedi}

Thomas Fredrik Weybye Barth (born in 1928), one of the towering figures of twentieth century, anthropology was a Norwegian citizen. Barth started out his anthropological career at the University of Chicago specializing in paleoanthropology and archaeology with cultural anthropology as minor subjects. At the age of 21 he received MA degree in 1949 and in 1951, he participated as paleologist in Braidwood's archaeological expedition to Jarmo in Iraq. He had however become increasingly interested in cultural anthropology and after having finished his paleontological work in Braidwood's expedition he stayed on in Kurdistan to study the social organization of the Kurds. In 1953, he submitted his book 'Principles of Social Organization in Southern Kurdistan' for $\mathrm{PhD}$ at the university of Oslo but the thesis was turned by the committee on the basis of a comment from Evans-Pritchard who said that in Oxford longer periods of fieldwork was required for a $\mathrm{PhD}$. After that academic setback Barth went to Cambridge where he was supervised by Edmund Leach (Barth 2007). On the basis of field material among the Pathans of Swat valley, Pakistan his thesis (published as 'Political Organizations among the Swat Pathans') was accepted as $\mathrm{PhD}$ degree in Social Anthropology in Cambridge in 1957. 
Even after several internationally well recognized publications University of Oslo did not offer any permanent job opportunities for him and in 1961 he was planning to accept a professorship at Columbia University, when University of Bergen saw his potential and offered him the opportunity to establish a Department of Social Anthropology from scratch. His new post at University of Bergen forced him to shoulder a multitude of simultaneous tasks in a small provincial university. He maintained active international collegiate relations and sent junior associates abroad as visiting scholars for systematic cooperation and exchange. Barth worked for more than a decade in University of Bergen (19611972). He taught in University of Oslo, Boston University and several other academic institutions.

Barth has done fieldwork in different ethnographic contexts from South Persia, Norway, Sudan, New Guinea, Bali, Oman, China and Bhutan, and made significant analytical contributions to different branches of anthropology, e.g. human ecology, political anthropology, economic anthropology, ethnicity, ritual and cosmology, complex civilizations and traditions of knowledge. Through out his whole career Barth has encouraged fellow anthropologists to combine basic theoretical research with applied work for several agencies (e.g. UNESCO in Iran, FAO in Sudan, World Bank in New Guinea and China). Another aspect of Barth's anthropological vision was his encouragement to stimulate cooperation between Department of Social Anthropology in Bergen and universities in different non-western countries, e.g. Sudan, Nepal, and China. It was such cooperation that made me familiar with Barth's approach.

In early 1990s, Tribhuvan-Bergen Human Ecology Research and Teaching Program was established. This was a formal program of two universities with disciplinary inputs from anthropology and archaeology of University of Bergen, and the Central Department of Sociology and Anthropology of Tribhuvan University. It also included the teaching component of thesis year students and in the first batch a total of 9 students were given thesis writing support from the program. I was one of the fellows for getting such opportunity. Professor Gunnar Haaland, Program Coordinator from Norwegian part, had taught me some theoretical and methodological issues in anthropology. At that time, I had an opportunity to read some articles 


\section{6| Madhusudan Subedi}

written by Fredrik Barth. In 1998, I was selected in first batch MPhil Program in Social Anthropology, University of Bergen, for foreign students under NORAD fellowship.

In early 1998, my senior colleague Saubhagya Shah, who was doing $\mathrm{PhD}$ in anthropology from Harvard University with a Fulbright Graduate Study Fellowship, had returned in Nepal for his fieldwork. We had a meeting in Kathmandu and I had asked him about the courses taught in Harvard and degree of difficulty faced by the students from developing countries. He was aware that I was preparing for MPhil program in University of Bergen, Norway. He shared his own experiences and had mentioned: 'Fredrik Barth is highly intellectual anthropologist from Norway. I am very impressed with his lectures and the way of his arguments, especially in ethnicity and political anthropology'. I had a dream to take Barth's lectures for acquiring social anthropological lenses to analyze human society and culture. I went to Bergen in August 1998 and studied for two years.

I first met Barth in November 1998 when he was invited to give some lectures for MPhil students. He focused his lectures on 'ethnicity and identity' and 'anthropological research'. He stressed the importance of concrete events of fieldwork observation, emphasis on the instrumentality of the individual actors with understanding consequences of micro-level interaction for macro-level structures. I had read his early papers on the subjects of his talk. While lecturing in class room his human warmth and frank engaged us and gave us his public presence.

His book, 'Political Leadership among Swat Pathans (1959)' is based on his PhD fieldwork. Barth did not follow the traditional anthropological approach of analyzing politics as an institution based on rules and norms defined by its function for society, but he described politics as an outcome of the choices and the alignments made by its participants. Barth concluded that the society is no doubt of moral system, but the political alignment of the persons within the polity was the aggregate result of myriad individual tactical decisions. There existed recognized forms of descent, property and regional identity, but no man's membership in any particular politically corporate group was ascribed to him. Landowning agnatic brothers or cousins might be allied or might choose to oppose each 
other. Such decisions were determined by individual judgment of advantage and strategy under particular circumstances (Barth $1959 ; 2007)$. If someone analyzes contemporary Nepali politics, his conclusions are very valid.

The ethnicity paper had been published in 1969. Barth was the editor of a book Ethnic Groups and Boundaries (1969). Barth suggested,

What is required is a combined theoretical and empirical attack: we need to investigate closely the empirical facts of a variety of cases, and fit our concepts to these empirical facts so that they elucidate them as simply and adequately as possible, and allow us to explore their implications. $(1969$, p. 10)

The authors in the book documented "situations where people changed their ethnic identities under pressure, or as a result of ecologic change or where they clung to them in minority situations by careful impression management, or used impression management to deny patent cultural differences that might have been given ethnic significance (Barth 2007, p.10).”

Barth focused on the interconnectedness of ethnic identities and argues that categorical ethnic distinctions do not depend on an absence of mobility, contact and information, but do entail social processes of exclusion and incorporation whereby discrete categories are maintained despite changing participation and membership in the course of individual life histories. Barth contends that ethnic identities are the product of continuous so-called ascriptions and self-ascriptions, whereby Barth stresses the interactional perspective of social anthropology on the level of the persons involved instead of on a socio-structural level. He argues that the ethnic identity becomes and is maintained through relational processes of inclusion and exclusion. The book, 'Ethnic Groups and Boundaries' has been one of the most cited social science publications and has played a major role in the scholarly debate about ethnicity and identity.

Here, Barth proposed that there is no one-to-one relationship between cultural differences and ethnic differences. It seems so obvious today: Ethnic identity does not grow naturally out of some shared cultural mass. It is rather the result of a social process of inclusion and exclusion.

Professor Barth's lectures were helpful in making me 


\section{8| Madhusudan Subedi}

understand a little better in what he was doing. Professor Gunnar Haaland told me to give presentation from the field materials of my MA thesis of Tribhuvan University. My classmates asked me a bunch of questions and I tried to satisfy them as far as possible. At last Barth mentioned, "...this is the way of exploring anthropologically and linking economy and society.... You can develop a good paper from your case materials." His advice to us was to be engaged in contemporary issues, to be intellectually humble, to recognize the researcher's privileged status and not to abuse it. I was greatly fascinated from his positive feedback, and became a fan of Barth's contributions and knew that Barth was a highly intellectual, remarkably versatile field researcher and a creative theoretician.

His book Balinese Worlds (1993) shows that he was an extraordinary ethnographer. Barth has highlighted that variation in complex society is not a mere 'surface disturbance' but a 'ubiquitous feature' that must become necessary part of analysis. People construct multiple and discrepant worlds by means of different traditions of knowledge available to them. We need to discover how much the different constructions are in fact distributed in their action and interactions (Barth 1993, p.271). Following this idea, I developed my conceptual framework of MPhil thesis. In understanding bodily afflictions, it is useful, in my view, to consider the types of questions that people ask themselves when they feel unwell, or when they experience any sudden, unexpected events in their daily lives. My theoretical framework, in my thesis, was mostly based on people's understanding of the culturally constructed reality. Following Barth, I argued that the reality can only be fully understood by examining the specific contexts in which an ill person's socio-economic organizations and dominant worldviews are patterned.

Knowledge in itself is the result of a learning process that is strongly influenced by a number of factors. Once internalized this knowledge becomes belief and when belief is expressed and communicated in symbolic form, it may contribute to develop particular cultural traditions. Each medical tradition provides a range of beliefs in terms of which people understand and act in the external 'world' in which they live, i.e. this 'world' constitute a culturally constructed reality. Belief about health and ill-health, as well as ideas about the role of healers may differ widely, and this influences the kinds of afflictions that people bring to healers, how they present themselves to the healers, and the types and quality of 
treatment that they are given. A major emphasis here is on exploring the variation within both lay and professional views. Connected to considerations of health concerns and peoples' knowledge, I used Barth's (1993:5) idea of variation to make a sense of it in people's health seeking behavior as:

(1) There are variations in the definition of illness, and each medical tradition provides a unique cause and treatment for a distinctive set of illnesses.

(2) There are variations in level of "expertise" within the same medical tradition in the population.

These variations are important for better understanding of the lives of people, through processes involving those people's own ideas and activities. The different styles of knowledge transmission generate deep differences in the form, scale, and the distribution of the knowledge (Barth 1990:640). The knowledge that is acquired, retained, and transmitted contains the key to explaining variations.

Although he is less well known as an historian of the discipline, he delivered five lectures on the British School as part of a series "Four Traditions in Anthropology" to mark the inauguration of the Max Planck Institute for Social Anthropology in its permanent buildings in 2002. (The lectures were later published in: Fredrik Barth, Andre Gingrich, Robert Parkin and Sydel Silverman. 2005. One Discipline, Four Ways: British, German, French and American Anthropology. The Halle Lectures. Chicago: Chicago University Press.).

Barth had an exceptionally long and rich career in anthropology, spanning six decades and more than a dozen field sites. His most influential contributions may have been his analysis of political strategy in Swat, his study of pastoral economy and ecology in Iran, and not least, his path breaking perspectives on ethnicity in Ethnic Groups and Boundaries (1969). However, Barth's early theoretical work, sometimes spoken of as 'transactionalism' (he preferred 'generative process analysis'), led to lively debates in the 1960s and 1970s, and his later work on knowledge and cosmologies has an enduring value in anthropology.

In Annual Review of Anthropology, Barth wrote an article, 'Overview: Sixty Years in Anthropology', which concludes:

The task is endless and ever self-transforming. For most of my lifetime I have seen it as a social science version of the naturalist's old task, of watching and wondering. We need to see our empirical 
work as an obligation, to acquit as best we can by critically using the variety of methods and concepts available to us at any one time, not by only performing the operations that are most fashionable or refined. But we equally need to regard every new empirical finding as a provocation, to rethink our assumptions and redesign our models. Pursued in this fashion, social anthropology promises to be as exciting in the future as it has been in the past. (2007, p. 15)

On 24 January 2016, Fredrik Barth passed away at the age of 87. I lost my teacher and external examiner of MPhil thesis, and above all a versatile field researcher and creative and innovative theoretician. His contribution to the discipline is immense, and has provided seminal stepping-off points for scholars.

Fredrik Barth, one of the highly influential figures of the twentieth-century social anthropology, impressed me immensely by his work on 'ethnicity and identity', 'social change', and 'variation'. Fredrik Barth was one of the most productive and original social anthropologists of his generation. His suggestion to the qualitative researchers is inspiring to me: "to build on what is there, not what you have brought".

Barth was one of Norway's most internationally recognized academics. His contribution to the discipline remains immense. He was crucial for the establishment and development of modern social anthropology at the University of Bergen and Oslo University. In his death, Norway has lost a father figure. Death is inevitable. The only one way we can pay tribute to him is by expanding his theoretical and methodological approaches in carrying forward his legacy and following his virtuous path. Professor Barth was an inspiring anthropologist and a very good teacher whose life influencing work has touched many anthropologists and sociologists.

I was fortunate enough to take his classes in University of Bergen in 1998. I still remember his remarks, "We need to nurture our young generation and give them opportunities." Several researchers in the anthropological community have been educated under Barth's arguments. He was absolutely the best teacher I ever had chances to meet in my two years academic life in Bergen, Norway. His passion to teach was matched by his compassion for his students. I have been benefitted from his work on ethnicity, identity, political strategies, and social change. More importantly, I was very impressed on his desire to encourage students and researchers in 
Dhaulagiri Journal of Sociology and Anthropology Vol.11, 2017|191

shaping anthropological thinking and arguments. I still feel proud that Professor Fredrik Barth was external examiner of my MPhil thesis.

\section{References}

Barth, F. (1959). Political Leadership among Swat Pathans. London: Athlone Press.

Barth, F. ed. (1969). Ethic Groups and Boundaries. Oslo: Universitetsforlaget.

Barth, F. (1993). Balinese Worlds. Chicago: University of Chicago Press.

Barth, F. (2007). Overview: Sixty Years in Anthropology. Annual Review of Anthropology, 36: 1-16.

Subedi, Madhusudan (ORCID: 0000-0001-6495-0601) is Professor and associated to the Central Department of Sociology, Tribhuvan University, and Patan Academy of Health Sciences, Nepal. For last 20 years, Subedi has focused on 'social determinants of health', 'women and health', 'pharmaceuticals', 'infectious diseases', 'caste system', 'informal networking', 'qualitative research methods' and 'polity and social transformation' in Nepal. Email: madhusudansubedi@gmail.com 